DOI: 10.20472/BMC.2020.011.006

\author{
IJACHI IJACHI \\ Covenant University, Ota, Nigeria \\ UWUIGBE UWALOMWA \\ Covenant University, Ota, Nigeria \\ STEPHEN OJEKA \\ Covenant University, Ota, Nigeria \\ OPEYEMI AJETUNMOBI \\ Covenant University, Ota, Nigeria \\ SIMON ILOGHO \\ Covenant University, Ota, Nigeria
}

\title{
THE IMPACT OF FOREIGN AID ON SUSTAINABLE DEVELOPMENT IN NIGERIA: AN ENVIRONMENTALLY ADJUSTED HUMAN DEVELOPMENT INDEX APPROACH
}

\begin{abstract}
:
The prime purpose of this research is to understand the relationship between foreign aid and sustainable development in Nigeria, using an environmentally adjusted human development index as a tool to measure sustainable development. Net Official Development Assistance \& Official aid received (ODA) was used as a proxy for foreign aid (ODA) while the proxy for sustainable development was the Environmentally Adjusted Human Development Index (EaHDI). The study used secondary sources of data. The researcher employed the use of Spearman's Correlation and Simple Linear regression analysis. The research could not find any statistically significant evidence that foreign aid has contributed significantly to sustainable development in Nigeria, even when corruption is controlled. The researcher recommends the adoption of sustainability reporting by the Nigerian Government, and follow up on donations by foreign aid donors to ensure accountability and transparency in the use of funds.
\end{abstract}

\section{Keywords:}

Foreign Aid, Sustainable Development, Environmentally Adjusted Human Development Index, Nigeria, Official Development Assistance, Environmental Performance Index

JEL Classification: Q56 


\section{Introduction}

Is Nigeria jinxed or is it a victim of what economists refer to as "resource curse". It appears to be a paradox that a developing country like Nigeria, sitting on over 100 trillion cubic feet of natural gas and 35 billion barrels of crude oil reserve (amongst other natural resources) is still a recipient of foreign aid. From oil boom to gloom or doom, oil and gas did not save the country from receiving over $\$ 400$ billion in aid which is six times the amount of foreign aid the United States pumped into restructuring the whole of Western Europe after World War II. (Burleigh, 2013).

As at the year 2018, the Gross Domestic Product (GDP) per capita for countries in Western Europe ranged from $\$ 42,931$ in France to $\$ 113,954$ in Luxembourg (Statistic Times, 2017). With all the cash and resources at the disposal of the Nigerian government, it is reasonable to expect significant economic growth and development. However, since gaining independence in 1960, the Gross Domestic Product (GDP) per capita in Nigeria has maintained an average of $\$ 1,736.15$ and has fluctuated between an all-time low of $\$ 1,145.80$ in 1968 to an all-time high of $\$ 2,563.10$ in 2014. The Gross Domestic Product per Capita in Nigeria as at the year 2018 sits at $\$ 2,396.30$ (Trading Economics, 2017).

This development has led several researchers to investigate the relationship between foreign aid and Gross Domestic Product as a measure of development in Nigeria. However, Gross Domestic Product as a measure of economic growth fails to account for social, human and environmental well-being, as an increasing Gross Domestic Product does not mean increasing economic welfare (St. Gallen Symposium, 2017). It is possible for two countries with the same level of Gross National Income per capita to have different human development outcomes. This scenario has given rise to the creation of the Human Development Index (HDI) which is a summary measure of the average achievement in key human development dimensions such as long life, education and a decent standard of living (United Nations Development Programme, 2017). According to Amir (2016), "GDP is good, but HDI measures Nigeria better".

Some researchers have indicated their preference for Human Development Index as a measure of development (Farhana \& Nausheen, 2014; Emmanuel, 2012; Nasim, Turkhan, \& Muhammad, 2011; Claudia, 2008; Mark \& Farhad, 2004). However, there have been recent calls for modification of the Human Development Index. According to Selim (2017), "it is human development accounting, not the HDI, which can portray the complete picture. The theme of discussion at the "Rio+20-United Nation Conference on Sustainable Development 2012" was all about empowering the Human Development Index with an environmental dimension (Maccari, 2014).

The essence of this research is to provide a better understanding of the relationship between foreign aid received and sustainable development in Nigeria, using Environmentally Adjusted Human Development Index (EaHDI) proposed by (ljachi, Uwuigbe, \& Ojeka, 2019). 


\section{$2 \quad$ Literature Review}

\section{$2.1 \quad$ Conceptual Review}

\section{Foreign Aid}

Foreign aid refers to all government resource transfers from one country to another (Kumar, 2017). Foreign aid is designed to promote economic development and welfare of developing countries. It excludes loans and credits for military purposes (OECD, 2017). It also excludes any resource transfers by private foreign investors (Kumar, 2017). It may be channelled through a multilateral development agency such as the World Bank or may be provided bilaterally from donor to recipient. It is mostly from developed nations or multilateral institutions to underdeveloped and developing countries. It may take the form of a gift, a grant or a "soft" loan (with at least $25 \%$ of the total). According to Kumar (2017), the following criteria must need to be met before any transfer of funds can be regarded as aid:

a. The transfer must be developmental or charitable

b. The transfer must be non-commercial

c. The transfer must be concessional

The Organisation for Economic Co-operation and Development manages a list of over 150 countries or territories with per capita incomes below $\$ 12,276$ as at the year 2010. Only aid given to countries on this list can be regarded as Official Development Assistance (ODA). The United Nations has a target that developed countries should devote $0.7 \%$ of their gross national income to Official Development Assistance (OECD, 2017).

\section{Sustainable Development}

According to the International Institute for Sustainable Development (2017), sustainable development is the development that meets the needs of the present without compromising the ability of future generations to meet their own needs. Sustainable development can be summarized into three pillars which are economic growth, environmental stewardship, and social inclusion. It is a form of development that cuts across all sectors of development in a country such as agriculture, infrastructure, energy development, water, transportation, amongst others. (World Bank, 2017). According to the United Nations Development Programme (2017), there is a universal call to action to end poverty, protect the planet and ensure that all people enjoy peace and prosperity. This universal call to action is called Global Goals or Sustainable Development Goals (SDGs). The Sustainable Development Goals are as follows;

$\begin{array}{ll}\text { i. } & \text { No poverty } \\ \text { ii. } & \text { Zero hunger } \\ \text { iii. } & \text { Good health and well-being } \\ \text { iv. } & \text { Quality education } \\ \text { v. } & \text { Gender Equality } \\ \text { vi. } & \text { Clean water and sanitation } \\ \text { vii. } & \text { Affordable and clean energy } \\ \text { viii. } & \text { Decent work and economic growth } \\ \text { ix. } & \text { Industry, innovation, and infrastructure }\end{array}$




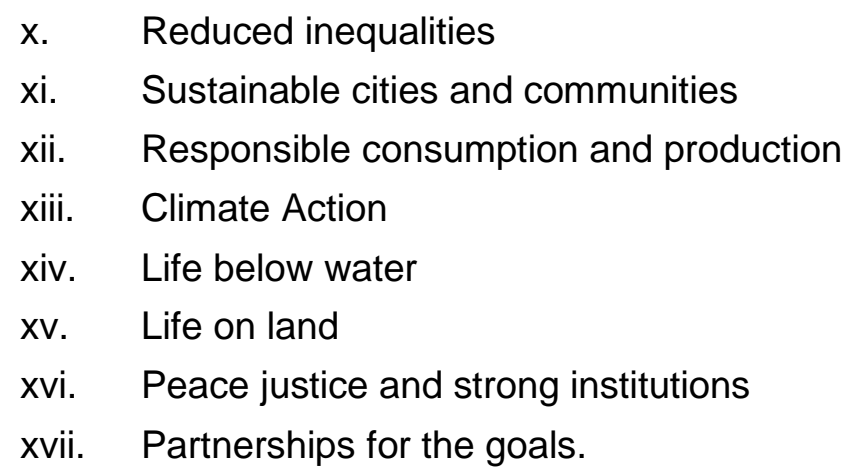

\section{Environmentally Adjusted Human Development Index (EaHDI)}

The Environmentally Adjusted Human Development Index (EaHDI) is a modified version of the Human Development Index proposed by ljachi, Uwuigbe, \& Ojeka (2019) meant to measure the level of progress towards sustainable development. Unlike the Human Development Index which incorporates only the economic and social dimensions of sustainability, the Environmentally Adjusted Human Development Index (EaHDI) incorporates all three pillars of sustainable development namely (the economy, the society and the environment). The Environmentally Adjusted Human Development Index (EaHDI) is computed as the geometric mean of the product of the Environmental Performance Index (EPI), Life Expectancy Index (LEI), Education Index (EI) and GNI Index (GNII). The EaHDI is expressed $n$ the formula below;

$$
\mathrm{EaHDI}=\sqrt[4]{E P I \times L E I \times E I \times G N I I}
$$

\subsection{Theoretical Review}

There are several theories of development. However, for this study, the researcher has decided to focus on Human Development theory and Sustainable Development Theory under which the current research falls.

\section{Human Development Theory}

Human development theory is a product of global discussions during the second half of the $20^{\text {th }}$ Century on the relationship between economic growth and development. In the early 1960s, economic growth had emerged as both a principal objective, an indicator, of national progress in many countries even though Gross Domestic Product (GDP) was never intended to be used as a measure of wellbeing. This situation led to increasingly loud calls to "dethrone" GDP. During the 1970 s and 80 s, development debate began focusing attention on using alternative measures that go beyond GDP to incorporate employment, redistribution of wealth and basic human needs (HDRO Outreach, 2017). The intention of the human development theory is not to belittle economic growth, but to rediscover its real purpose (Human Development Foundation, 2017).

Human development theory goes beyond the richness of the economy in which we live towards expanding the richness of human life. This approach aims to provide fair opportunities and choices for everyone. (HDRO Outreach, 2017). The significant aspects of the human development paradigm according to the Human Development Foundation (2017) include the following: 
- People must be at the centre of concerns for any development discussion.

- Enlargement of all human choices beyond income.

- Developing human capabilities through investment in people, and full utilisation of those capabilities, by providing the enabling framework for growth and empowerment

- The four pillars of Human development are: equity, production, sustainability, and empowerment

The human development approach to development was developed by the economist Mahbub UI Haq, who anchored his work on Amartya Sen's work on human capabilities, which was framed in terms of people's ability to be fed, sheltered, educated, live a healthy life, vote, do work, vote and participate in community life (HDRO Outreach, 2017).

However, the current research does not adopt the human development approach as it does not correctly incorporate the environmental dimension or development or sustainable development.

\section{Sustainable Development Theory}

Sustainable development has been defined by the United Nations (2017) as development that meets the needs of the present without compromising the ability of future generations to meet their own needs. Sustainable development involves building an inclusive, sustainable and resilient future for humans and the planet. In order for sustainable development, there is a need to harmonise three core elements: environmental protection, social inclusion, and economic growth. These three interconnected elements are critical for the well-being of societies and individuals.

Elizabeth, Peri, and Stewart (2017) identified four models of sustainable development that depict the evolution of environmental sustainability. These models begin with the "Mickey Mouse Model", which gave way to the "Three Pillars Model", followed by the "Three Nested Ring Model", and most recently, "The Nested Dependencies Model" which suggests that the economy and society are constrained within the limits of the environment. The researcher has adopted the Nested Dependencies Model of Sustainable Development for the current research because it is the most holistic approach to sustainable development.

\subsection{Empirical Review}

Covering the period of 1960-2010, Emmanuel (2012) studied development aid and human development in Nigeria by employing two-stage least squares estimation to analysing data. The study found that there is a negative relationship between development aid and human development. The findings of Emmanuel (2012) are similar to that of Claudia (2008) who investigated the effectiveness of aid in promoting human development after controlling for reverse causality. The research, however, failed to incorporate environmental factors in its assessment of human development. The focus of the current research is to incorporate environmental factors in assessing the relationship between foreign aid and sustainable development in Nigeria.

The findings of Nasim, Turkhan, and Muhammad (2011) and Olatujoye, Fajobi, and Adeniran (2016) are contrary to that of Emmanuel (2012) and Claudi (2008). Nasim et al. (2011) studied the effectiveness of foreign aid in the unique context of a set of social outcomes in Pakistan. Their findings are consistent with literature that foreign aid contributes to human development and National Development. Olatujoye et al. (2016) studied foreign aid intervention and national development in Nigeria (with a particular focus on Akure South Local Government Area of Ondo 
State) by employing a qualitative method of data collection, interviews, and content analysis. Their findings revealed that foreign aid had played a role in the development of the communities studied and they recommended that foreign aid should be channelled towards rural communities in need of critical infrastructures. Though geographical location may have played a role in the difference in findings of Nasim et al. (2011) and that of Emmanuel (2012) or Claudia (2008), same cannot be said about the findings of Olatujoye et al. (2016) which was conducted within same country as that of Emmanuel (2012). A difference in methodology and research data may be responsible for the different findings of Emmanuel (2012) and Olatujoye et al. (2016). One of the underlying features of the studies carried out by Nasim et al. (2011) and Olatujoye (2016) is the fact that both researchers did not incorporate environmental factors in their studies.

Ahmad, Alireza, Parvaneh, and Maryam (2011) studied the relationship between Environmental Performance and Human Development in countries around the World between the period of 2006-2010. Panel data regression model was applied to overall Environmental Performance Index data (from the Yale Center for Environmental Law and Policy) and Human Development Index data (from the World Bank) across 114 countries. Their findings showed that there was a positive and significant relationship between EPI and HDI for the whole countries examined. They also found that for developing countries suffering from environmental degradation, human development index does not necessarily improve Environmental Performance. This study, however, did not link foreign aid to any of the variables studied. Furthermore, while there may be a significant positive relationship between EPI and HDI at the global level, there is still a need to carry out similar research at each the country level.

Margaret (2008) in a study of the effects of foreign aid on perceptions of political corruption in Sub-Saharan Africa employed multivariate regression and proposed that Sub-Saharan countries receiving more foreign aid would be more likely to maintain high levels of perceived corruption. Using Nigeria as a case study, the research also found that increases in foreign aid paralleled improved perceptions of political corruption and that Nigeria's reform initiative during the Obasanjo regime (1999-2007) was a major determining factor in this perception shift. Though this research was able to relate foreign aid with political corruption in Sub-Saharan Africa, it does not address the effects of foreign aid on sustainable development in Nigeria. This gap in knowledge is one of the reasons why there is a need for this current research.

In a study by Mark \& Farhad (2004), the links between conflict aid and human development in 94 developing countries were examined. They found that conflict and aid are negatively related to Human Development Index (HDI) levels and that aid does not offset the negative impact of conflict on human development. They also found that aid is neither more nor less effective in terms of its impact on human (2012). This finding of Mark \& Farhad (2004) are in agreement with that of Todd (2007) who studied the impact of foreign aid on human development index in 87 developing countries (from the year 1980-2000) and found that increased foreign aid is associated with lower Human Development Index (HDI) levels. The findings of Mark \& Farhad (2004) and Todd (2007) are however contrary to that of Masoud \& Said (2017) who applied quantile regression on data from 124 developing countries from 1980 to 2013 and found a positive relationship (which is strongest in countries with low level of human development) between foreign aid and human development index. This disparity may be because the study by Mark \& Farhad (2004) was specifically focused on conflict aid. Both Mark \& Farhad (2004), Todd (2007) and Masoud \& Said (2017) however employed the use of Human Development Index (as a measure of development) which does not incorporate environmental factors. 
Kuznets (1955), suggested that the relationship between income inequality and economic growth has an ' $n$-shaped' feature, meaning that if foreign aid policies are channelled towards industrialisation, equality will be achieved. This view was however debunked by Piketty (2014) who suggested that the relationship between inequality and economic growth is 'u-shaped', meaning sustainable development can be achieved if foreign aid is channelled towards reducing inequality. After reviewing close to 200 papers, Asongu (2016) came to a conclusion that supports the position of Piketty by suggesting that sustainable and inclusive development is achievable through a policy reversal from the perspective of Kuznets towards the view of Piketty. The difference in opinion by Kuznets and Piketty may be due to time difference as the position by Kuznets was stated during the 'industrial age' while that of Piketty was stated during the 'information age'. Furthermore, Kuznets, Piketty, and Asongu focused more on qualitative studies of foreign aid and sustainable development. The need for a quantitative study of the relationship between foreign aid and sustainable development is critical to the current research.

Simbarache (2012), in a study of foreign aid and sustainable development in Africa, employed content analysis of data from secondary sources to conclude that foreign aid in itself is not inherently evil but rather it is the misuse of foreign aid that is dangerous to development. Sambarache's research, however, did not focus on Nigeria but instead was centred on Zimbabwe's experience of debt trap and service delivery. Funso \& Dare (2010) carried out a similar study earlier and came to a similar conclusion to that of Simbarache. They, however, went further to blame the low impact of foreign aid on successive corrupt and inept leadership. Both researchers, however, did not employ quantitative computation in their study of the role foreign aid plays in economic development.

Barry, Mohammod, Jonathan, Dale and Jose (2011) studied the impact of environmental constraints on Human Development through the use of the International Futures (IFs) integrated forecasting system in different scenarios to discover that environmental constraints, directly and indirectly, could constrain or reverse development as measured by Human Development Index (HDI). The findings of this research are one of the premises upon which the current research has adopted an environmentally adjusted Human Development Index (HDI) as a measure of sustainable development.

Andrew (2009), through a study, tried to distinguish between what literature says and what reality says concerning foreign aid and development in Africa. From the research, it was found that even when a country may be perceived to have attained significant levels of macroeconomic growth, there could still be widespread poverty in the grassroots as a result of the fact that too much attention has been paid to money and macroeconomic "buzzwords" at the expense of aid performance. The findings of the study by Andrew (2009) forms the premise for the current research as there is need to look beyond economic development and pay more attention to sustainable development which is a more holistic and realistic measure of reality.

Ann and Andersson (2007) in a study of the performance of over 60 countries between 1995 and 2000 found that China followed by Nigeria demonstrated the highest efficiency index which reflects how well a country is using its resources. However, when linking country efficiency index with aid, there was no clear pattern to be found. The research by Ann and Andersson (2007) employed the use of Gross Domestic Product as a measure of development which fails to incorporate human and environmental dimensions of development. Love \& Staffan (2013) in a similar research examined how aid affects Human Development Index (HDI) in Sub-Saharan Africa and discovered that while aid has a significant positive effect on Human Development 
Index (HDI), the type of effects and time lags for the effects to be felt according to the type of aid. The recommendations of their research which includes country-specific study and consideration of corruption, are taken care of by the current research.

Lorena et al. (2012) in a study meant to develop a Human Development Index HDI) that incorporates economic inequality and environmental quality came up with an integrated Human Development Index (HDI). It was found that the Integrated Human Development Index (HDI), when applied to 169 coastal municipalities in Mexico, was always lower than the official Human Development Index (HDI). There is, however, need to expand the scope of this research to countries around the world, across several years.

Maccari (2014) carried out a study of the relationship between environmental sustainability human development from an environmental perspective. The study found that the relationship between $\mathrm{HDI}$ and EPI, when plotted on a graph, was U-shaped. The study also introduced a new measure known as the Environmental Human Development Index which rebalances the concept of human development within a sustainability framework. This new Environmental Human Development Index was also discussed in the light of the Kyoto protocol agreement. This current research adopts the new measure known as Environmental Human Development Index which was created by Maccari (2014) in order to study the relationship between Foreign and Sustainable Development in Nigeria.

\section{The Gap in Literature}

The above review provides an insight into the work of scholars and researchers related to the subject of this research work. From the diversified approaches and varied angles undertaken by these experts, there is a consensus gap in literature mainly as a result of the exclusion of environmental factors in the measurement of development. This research work intends to fill the dearth in the literature by studying the relationship between foreign aid and sustainable development in Nigeria by using the Environmentally Adjusted Human Development Index (EaHDI) as a measure of sustainable development.

\section{$3 \quad$ Methodology}

\subsection{Research Design}

The researcher used Ex Post Facto Research Design to study the relationship between foreign aids and sustainable development in Nigeria because Ex Post Facto Research Design uses what already exist and looks backwards to explain why.

This research employed the use of secondary data to study the relationship between foreign aid and sustainable development in Nigeria by incorporating environmental performance index in the measure of the human development index. Correlation technique was employed to answer the research questions and to test the hypotheses. 


\subsection{Population of Study}

The area of study for this research work covers Nigeria. This area of study also serves as the population of the study. The research period covered from 2006 to 2018 and was chosen based on the availability of data. Due to the biennial nature of the Environmental Performance Index Report, only seven years $(2006,2008,2010,2012,2014,2016$, and 2018) will be considered for this study.

\subsection{Method of Data Collection}

This study employed the use of only secondary data. Data for Net Official Development Assistance (ODA), and sub-indices for Human Development Index (HDI) such as the Life Expectancy Index (LEI), Education Index (EI) and GNI Index (GNII) were sourced from the WorldBank Databank while data on Environmental Performance Index were sourced from the Annual EPI Reports for the selected years. Data on Corruption Perception Index (CPI) was sourced from Transparency International. The Environmentally Adjusted Human Development Index (EaHDI) for the selected years were derived using the following formula proposed by ljachi, Uwuigbe, \& Ojeka (2019);

$\mathrm{EaHDI}=\sqrt[4]{E P I \times L E I \times E I \times G N I I}$

Where:

Life Expectancy Index $(\mathrm{LEI})=\frac{L E B-20}{85-20}$

Education Index $(\mathrm{EI})=\frac{\frac{M Y S I+E Y S I}{2}}{2}$

GNI Index $($ GNII $)=\frac{\ln (\text { GNIpc })-\ln (100)}{\ln (75,000)-\ln (100)}$

LEB $=$ Life Expectancy at Birth

$\mathrm{MYSI}=$ Mean Years of Schooling Index, which is the number of years a person aged 25 or more spent in formal education (computed as $\frac{\text { Mean Years of Schooling }}{15}$ )

EYSI = Expected Years of Schooling Index, which is the expected years of schooling for children Expected Years of Schooling

under 18 years of age (computed as

$G N I_{p c}=$ Purchasing Power Parity (PPP) Gross National Income per capita

\subsection{Method of Data Analysis}

Correlation refers to a technique that measures the strength of the association between two variables. The two widely used measures of correlation are Spearman's rank correlation coefficient and Pearson's Product Moment Correlation Coefficient. This research makes use of the Pearson's Product Moment Correlation Coefficient because according to Oakshott (2006) it is 
best used when the data is on the interval scale (i.e. when the data consists of actual measurements). For this research, the researcher has adopted 0.05 as the level of significance.

Before a regression equation can be used effectively as a predictor for another variable, it is necessary to decide how well it fits the data using the Coefficient of determination. The coefficient of determination measures the proportion of the variation in the dependent variable explained by the variation in the independent variable. It is given by $r^{2}$.

In order to obtain an unbiased estimate of a causal effect in the regression analysis for this study, the researcher needs to ensure that the coefficient on the causal variable of interest does not suffer from Omitted Variable Bias (OVB). In order to eliminate the possibility of Omitted Variable Bias (OVB), the researchers also added data on Corruption in Nigeria as a control variable to the regression analysis.

\subsection{Model Specification}

The following model is based on Pearson's product-moment correlation coefficient $(r)$ and is employed by the researcher towards understanding the nature of the relationship between Foreign aid and sustainable development in Nigeria.

r. ODA.EAHDI $=\frac{n \sum O D A * E a H D I-\sum O D A \sum E a H D I}{\sqrt{\left[n \sum O D A^{2}-\left(\sum O D A\right)^{2}\right]}\left[n \sum E a H D I^{2}-\left(\sum E_{A H D I}^{2}\right)\right]}$

Model for Null Hypothesis One (Ho1)

Where;

$\mathrm{n}=$ number of observations

ODA = Net Official Development Assistance

EaHDI = Environmentally Adjusted Human Development Index

The following model is based on simple linear regression formula and is employed by the researcher towards predicting the dependent variable with the independent variables in this research.

Simple linear regression model for Null Hypothesis One (Ho1)

$\mathrm{EaHDI}=\beta \mathrm{O}+\beta_{1} \mathrm{ODA}+\mathrm{e}$

$\beta_{\circ}=\frac{n \sum(O D A)(E a H D I)-\sum O D A \sum E a H D I}{n \sum O D A^{2}-\left(\sum O D A\right)^{2}}$

$\beta_{1}=\frac{\sum E a H D I}{n}-\beta O \frac{\sum O D A}{n}$

Where

$\beta o=$ Constant

$\beta 1=$ Multiplier of independent variables 


$$
\mathrm{e}=\text { Random Variables }
$$

$\mathrm{n}=$ number of observations

ODA = Net Official Development Assistance

EaHDI = Environmental Human Development Index

\subsection{Operationalization of Variables}

Net Official Development Assistance (ODA) was used as a measure of foreign aid while Environmentally Adjusted Human Development Index (EaHDI) was used as a measure of sustainable development. Corruption Perception Index (CPI) was used as a control variable. Environmentally Adjusted Human Development Index is computed for each year by finding the geometric mean of the product of Environmental Performance Index, Life Expectancy Index (LEI), Education Index (EI) and GNI Index (GNII).

\subsection{Hypotheses of the Study}

Ho1: There is no (statistically significant) relationship between Foreign Aid and the Environmental Human Development Index (EHDI) of Nigeria.

\section{Discussion of Findings}

This section entails the presentation of data, analysis of data and discussion of findings from the analysis of data.

\subsection{Data Presentation and Descriptive Statistics}

Below, is a tabular presentation of the data used for this research.

Table 4.1 Research Data

\begin{tabular}{|l|l|l|l|l|l|l|l|}
\hline YEAR & LEI & EI & GNII & EPI & EaHDI & ODA (CONSTANT 2015 US \$) & CPI \\
\hline 2006 & 0.443 & 0.428 & 0.563 & 0.445 & 0.466852 & $11,278,060,000$ & 0.22 \\
\hline 2008 & 0.46 & 0.435 & 0.571 & 0.562 & 0.50339 & $1,234,100,000$ & 0.27 \\
\hline 2010 & 0.475 & 0.407 & 0.585 & 0.402 & 0.461761 & $1,991,920,000$ & 0.24 \\
\hline 2012 & 0.489 & 0.437 & 0.591 & 0.4014 & 0.474503 & $1,784,120,000$ & 0.27 \\
\hline 2014 & 0.503 & 0.471 & 0.605 & 0.392 & 0.486864 & $2,252,790,000$ & 0.27 \\
\hline 2016 & 0.516 & 0.475 & 0.601 & 0.5827 & 0.541272 & $2,498,190,000$ & 0.28 \\
\hline
\end{tabular}

Sources - World Bank, Transparency International, United Nations Development Programme, Researcher's computation (2018) 
Table 4.2 Descriptive Statistics of Research Data

\begin{tabular}{|c|c|c|c|c|c|c|c|c|}
\hline & \multirow{2}{*}{$\begin{array}{l}\mathrm{N} \\
\text { Sta } \\
\text { tisti } \\
\mathrm{C}\end{array}$} & \multirow{2}{*}{$\begin{array}{l}\text { Range } \\
\text { Statistic }\end{array}$} & \multirow{2}{*}{$\begin{array}{l}\text { Minimum } \\
\text { Statistic }\end{array}$} & \multirow{2}{*}{$\begin{array}{l}\text { Maximum } \\
\text { Statistic }\end{array}$} & \multicolumn{2}{|l|}{ Mean } & \multirow{2}{*}{$\begin{array}{l}\text { Std. } \\
\text { Deviation } \\
\text { Statistic }\end{array}$} & \multirow{2}{*}{$\begin{array}{l}\text { Variance } \\
\text { Statistic }\end{array}$} \\
\hline & & & & & Statistic & $\begin{array}{l}\text { Std. } \\
\text { Error }\end{array}$ & & \\
\hline V1 & 6 & 10 & 2006 & 2016 & 2011.00 & 1.528 & 3.742 & 14.000 \\
\hline LEI & 6 & .073 & .443 & .516 & .48100 & .011097 & .027181 & .001 \\
\hline $\mathrm{El}$ & 6 & .068 & .407 & .475 & .44217 & .010685 & .026172 & .001 \\
\hline $\begin{array}{l}\text { GNI } \\
\text { I }\end{array}$ & 6 & .042 & .563 & .605 & .58600 & .006748 & .016529 & .000 \\
\hline EPI & 6 & .1907 & .3920 & .5827 & .464183 & .0351194 & .0860247 & .007 \\
\hline $\begin{array}{l}\mathrm{Ea} \\
\mathrm{HDI}\end{array}$ & 6 & $\begin{array}{l}.0795109 \\
2347953 \\
45 \\
\end{array}$ & $\begin{array}{l}.4617612 \\
4940720 \\
40\end{array}$ & $\begin{array}{l}.5412721 \\
7288673 \\
90 \\
\end{array}$ & $\begin{array}{l}.489107 \\
0357808 \\
73\end{array}$ & $\begin{array}{l}.0120921 \\
7373409 \\
3 \\
\end{array}$ & $\begin{array}{l}.0296196 \\
5552961 \\
2 \\
\end{array}$ & .001 \\
\hline $\begin{array}{l}\text { OD } \\
A\end{array}$ & 6 & $\begin{array}{l}\$ 10,043 \\
960,000\end{array}$ & $\begin{array}{l}\$ 1,234,1 \\
00,000\end{array}$ & $\begin{array}{l}\$ 11,278 \\
060,000\end{array}$ & $\begin{array}{l}\$ 3,506,5 \\
30,000.0 \\
0\end{array}$ & $\begin{array}{l}\$ 1,564,2 \\
88,654.6 \\
20\end{array}$ & $\begin{array}{l}\$ 3,831,7 \\
09,014.2 \\
44\end{array}$ & $\begin{array}{l}14681993969 \\
840000000.0 \\
00\end{array}$ \\
\hline $\mathrm{CPI}$ & 6 & .06 & .22 & .28 & .2583 & .00946 & .02317 & .001 \\
\hline $\begin{array}{l}\text { Vali } \\
\mathrm{d} \mathrm{N} \\
\text { (list } \\
\text { wis } \\
\text { e) }\end{array}$ & 6 & & & & & & & \\
\hline
\end{tabular}

Sources - Secondary data in Table 4.1.

Table 4.2 above represents the descriptive statistic of the research data. The information provided by the table includes the minimum values, maximum values, mean values and standard deviations for all variables used in the research work for each of the selected years in the period.

\subsection{Data Analysis \& Test of Hypothesis}

\section{Test of Hypothesis One (Ho1)}

Ho1: There is no (statistically significant) relationship between Foreign Aid and the Environmental Human Development Index (EHDI) of Nigeria. 
Table 4.3: Correlation between ODA \& EaHDI (SPSS Output)

Correlations

\begin{tabular}{|ll|l|l|}
\hline & & EaHDI & ODA \\
\hline EaHDI & $\begin{array}{l}\text { Pearson } \\
\text { Correlation }\end{array}$ & 1 & -.332 \\
& Sig. (2-tailed) & & .520 \\
& $\mathrm{~N}$ & 6 & 6 \\
\hline ODA & Pearson & -.332 & 1 \\
& Correlation \\
& Sig. (2-tailed) & .520 & \\
& $\mathrm{~N}$ & 6 & 6 \\
\hline
\end{tabular}

Table 4.4: Partial Correlation between ODA \& EaHDI, Controlling for Corruption (SPSS Output)

Correlations

\begin{tabular}{|lll|l|l|}
\hline \multicolumn{2}{|c|}{ Control Variables } & EaHDI & ODA \\
\hline CPI & EaHDI & Correlation & 1.000 & .560 \\
& Significance (2-tailed) & & .326 \\
& Df & 0 & 3 \\
\hline & Correlation & .560 & 1.000 \\
& Significance (2-tailed) & .326 & \\
& Df & 3 & 0 \\
\hline & & & \\
& & & & \\
& & &
\end{tabular}

Table 4.5: Simple Linear Regression between ODA \& EaHDI (SPSS Output)

\section{Coefficients $^{\mathrm{a}}$}

\begin{tabular}{|c|c|c|c|c|c|c|c|}
\hline \multirow[b]{2}{*}{ Model } & \multicolumn{2}{|c|}{$\begin{array}{l}\text { Unstandardized } \\
\text { Coefficients }\end{array}$} & \multirow{2}{*}{$\begin{array}{l}\begin{array}{l}\text { Standardized } \\
\text { Coefficients }\end{array} \\
\text { Beta }\end{array}$} & \multirow[b]{2}{*}{$\mathrm{t}$} & \multirow[b]{2}{*}{ Sig. } & \multicolumn{2}{|c|}{$\begin{array}{l}95.0 \% \\
\text { Interval for B }\end{array}$} \\
\hline & B & $\begin{array}{l}\text { Std. } \\
\text { Error }\end{array}$ & & & & $\begin{array}{l}\text { Lower } \\
\text { Bound }\end{array}$ & $\begin{array}{l}\text { Upper } \\
\text { Bound }\end{array}$ \\
\hline 1 (Constant) & .498 & .018 & & 27.590 & .000 & .448 & .548 \\
\hline
\end{tabular}


\begin{tabular}{|l|l|l|l|l|l|l|l|} 
ODA & $\begin{array}{l}-2.570 \mathrm{E}- \\
12\end{array}$ & .000 & -.332 & -.705 & .520 & .000 & .000 \\
\hline
\end{tabular}

a. Dependent Variable: EaHDI

As inferred from Table 4.3, there is a negative correlation between ODA and EaHDI but when CPI is introduced as a control variable as seen in Table 4.4 above, there is a positive correlation between ODA and EaHDI. While the correlation coefficient of -0.332 in Table 4.3 depicts a weak relationship, the correlation coefficient increases to 0.520 in table 4.4 when the effect of corruption is controlled. This means an increase in coefficient of determination from $11.02 \%$ (i.e $0.332 \times-0.332)$ to $31.36 \%(0.56 \times 0.56)$. The p-values of 0.326 in Table 4.3 and 0.326 in Table 4.4 are more than the level of significance value 0.05 ; hence the weak negative relationship between ODA and EaHDI in Table 4.3 and the positive relationship between ODA and EaHDI in Table 4.4 are not statistically significant.

From the information provided by the regression output in Table 4.5 above, the statistical model that demonstrates the relationship between ODA and EaHDI is as follows:

$\mathrm{EaHDI}=\beta \mathrm{O}+\beta_{1} \mathrm{ODA}+\mathrm{e}$

Which is translated as EaHDI $=0.498-0.000000000002570 D A+e$

Based on the findings above, we fail to reject the null hypothesis and cannot accept the alternative. This implies that we cannot conclude that there is a strong positive statistically significant relationship between ODA and EaHDI in Nigeria.Human Development Index (EHDI) of Nigeria.

\section{Conclusion and Recommendations}

\subsection{Conclusion}

Based on the findings of this research, the researchers cannot conclude that foreign aid has contributed significantly to sustainable development in Nigeria, even when corruption was used as a control variable. It is evident that the use of Environmentally Adjusted Human Development Index (EaHDI) as a tool to measure progress towards sustainable development has thrown some doubt on the perceived positive impact of foreign aid on sustainable development as suggested by Olatujoye et al. (2016) and Nasim et al. (2011). Based on the findings of this research, the findings of Emmanuel (2012), Ahmad et al. (2011) and Claudia (2008) are more plausible.

\subsection{Recommendations}

The following is a set of recommendations proffered by the researchers:

a. Foreign aid donors should follow-up on their donations to ensure accountability and transparency in the use of funds by receiving countries.

b. Corruption must be tackled in Nigeria in order to increase the efficiency of resource use. 
c. Nigerian government should adopt the Environmentally Adjusted Human Development Index (EaHDI) as a tool for sustainability reporting in Nigeria, in order to promote accountability and transparency in the use of foreign aid.

\subsection{Contribution to Knowledge}

This research work investigated the relationship between foreign aid and sustainable development in Nigeria. The following are some of the contributions this research has made to the existing body of knowledge;

This research discovered that we could not accept the notion that foreign aid has contributed significantly to sustainable development in Nigeria, even when corruption is controlled.

\subsection{Suggestions for further study}

The most significant limitation of this research is the lack of consistent data on the Environmental Performance Index (EPI) and change in methodologies for computing the Environmental Performance Index. This paucity of data hindered the scope of the research to the years 20062016. Though this research was unable to prove that foreign aid has any statistically significant positive impact on sustainable development in Nigeria, this may be as a result of the limitations encountered in the course of this research. There is a need to carry out more studies to better understand the relationship between Foreign Aid and Sustainable Development in Nigeria, using consistent data that cover a more extended period.

Furthermore, there is a need for further research that will lead to the development of standard and consistent indices that measure sustainable development. The Environmental Performance Index used in the Environmentally Adjusted Human Development Index (EaHDI) is inconsistent and changes every year, making it difficult to compare data for several years. 


\section{References}

Ahmad, J. S., Alireza, K., Parvaneh, S., \& Maryam, L. (2011). Environmental Performance and HDI: Evidence from Countries Around the World. Middle-East Journal of Scientific Research, 294-301.

Amir, B. (2016, May 25). GDP is good, but HDI measures Nigeria better. Retrieved from Dailytrust: https://www.dailytrust.com.ng/news/opinion/gdp-is-good-but-hdi-measures-nigeriabetter/148316.html

Andrews, N. (2009). Foreign aid and development in Africa: What the literature says and what the reality is. Journal of African Studies and Development, 8-15.

Ann, V., \& Andersson, P.-A. (2007). Foreign aid, economic growth and efficiency development: A Data Envelopment Analysis Approach. Karlstad: Swedish Agency for Development Evaluation.

Asongu, S. (2016). Reinventing Foreign Aid for Inclusive and Sustainable Development: Kuznets, Piketty and The Great Policy Reversal. Journal of Economic Surveys, 736-755.

Barry, B. H., Mohammod, T. I., Jonathan, D. M., Dale, S., \& Jose, R. S. (2011). Forecasting the Impacts of Environmental Constraints on Human Development. UNDP.

Burleigh, M. (2013, August 9). Nigeria, a country so corrupt it would be better to burn our aid money. Retrieved from The Daily Mail: http://www.dailymail.co.uk/debate/article-2387359/Nigeriacountry-corrupt-better-burn-aid-money.html

Claudia, R. W. (2008). Foreign Aid and Human Development: The Impact of Foreign Aid to the Health Sector. Southern Economic Journal, 188-207.

Elizabeth, R. S., Peri, M., \& Stewart, W. (2017, 12 21). Skringar et al 2013 - Systemic and institutional barriers to core sustainability tackling the elephant in the room. Retrieved from Slideshare: https://www.slideshare.net/ElizabethRSkringar/skringar-et-al-2013-systemic-and-institutionalbarriers-to-core-sustainability-tackling-the-elephant-in-the-room-45776204

Emmanuel, O. O. (2012). Five Decades of Development Aid to Nigeria: The Impact on Human Development. Journal of Economics and Sustainable Development, 32-42.

Environmental Performance Index. (2016). Yale Epi 2016 Report. Environmental Performance Index.

Farhana, R., \& Nausheen, R. (2014). Effectiveness of Foreign Aid and Social-Economic Variables on HDI: A Comparative Study between Bangladesh and India. Journal of Business Studies, 115-136.

Funso, A., \& Dare, A. (2010). Foreign aid, the Third World's debt crisis and the Implication for economic development: The Nigerian experience. African Journal of Political Science and International Relations, 120-127.

HDRO Outreach. (2017, 12 22). What is Human Development. Retrieved from United Nations Development Programme: http://hdr.undp.org/en/content/what-human-development

Human Development Foundation. (2017, 12 22). HDF/Human Development Definition. Retrieved from Internet Archive Wayback Machine: 
https://web.archive.org/web/20091126123359/http://www.hdf.com/dotnetnuke/humandevelop ment/Introduction.aspx

Ijachi, I., Uwuigbe, U., \& Ojeka, S. (2019). Accounting for Sustainable Development: The Environmentally Adjusted Human Development Index. Unpublished Manuscript.

International Institute for Sustainable Development. (2017, November 20). Sustainable Development. Retrieved from IISSD: http://www.iisd.org/topic/sustainable-development

Kumar, M. (2017, November 20). Foreign Aid: Meaning and Types. Retrieved from Economics Discussion: http://www.economicsdiscussion.net/foreign-aid/foreign-aid-meaning-and-types/11832

Kuznets, S. (1955). Economic Growth and Income Inequality. American Economic Review, 1-28.

Lorena, P. R., Jose, L. F., lleana, E., Carlos, I. V., Georges, S., Isaac, A. A., \& Guillermo, A. V. (2012). Environmental quality and equity in the Human Development Index: an integrated index for the Local Agenda 21 case study. Journal of Economic and Sustainable Development, 39 - 51.

Love, H., \& Staffan, S. (2013). How Does Aid Affect Human Development Index (HDI) in Sub-Saharan Africa. Gothenburg: University of Gothenburg.

Maccari, N. (2014, March 15). Environmental Sustainability and Human Development: A Greening of Human Development Index Bby Norma Maccari. Retrieved from SSRN: Maccari, Norma, Environmental Sustainability and Human Development: A Greening ofhttp://dx.doi.org/10.2139/ssrn.2426073

Margaret, K. W. (2008). The Effects of Foreign Aid on Perceptions of Political Corruption in Sub-Saharan Africa. Orlando: University of Central Florida.

Mark, M., \& Farhad, N. (2004). Aid, Conflict and Human Development. Glasgow: University of Glasgow.

Masoud, R. M., \& Said, S. M. (2017). Foreign Aid and Human Development: A Quantile Regression Approach. Journal of Economics, Management and Accounting, 27-41.

Nasim, S. S., Turkhan, A. A., \& Muhammad, A. (2011). Effectiveness of Foreign Aid and Human Development. Pakistan Development Review, 853-862.

Oakshott, L. (2006). Essential Quantitative Methods for Business, Management and Finance. Hampshire: Palgrave Macmillan.

OECD. (2017, November 20). Official Development Assistance. Retrieved from OECD: https://data.oecd.org/oda/net-oda.htm

Olatujoye, O. O., Fajobi, T. A., \& Adeniran, A. I. (2016). Foreign Aid Intervention and National Development in Nigeria: A Study of Akure South Local Government Area of Ondo State. Arts and Social Sciences Journal, 1-6.

Piketty, T. (2014). Capital in the Twenty First Century. Massachusetts: The Belknap Press of Harvard University Press. 
Selim, J. (2017, November 20). The Human Development Index - what it is and what it is not. Retrieved from UNDP Human Development Reports: http://hdr.undp.org/en/hdi-what-it-is

Simbarache, G. (2012). Interrogating Foreign Aid and the Sustainable Development Conundrum in African Countries: A Zimbabwean Experience of Debt Trap and Service Delivery. International Journal of Politics and Good Governance, 1-20.

St. Gallen Symposium. (2017, November 20). GDP Not Good Enough: The Need for a New Metric for Growth in a Changing World. Retrieved from Huffpost: https://www.huffingtonpost.com/stgallen-symposium/gdp-not-good-enough-the-n_b_9495070.html

Statistic Times. (2019, March 20). List of European countries by GDP per capita. Retrieved from Statistics Times: statisticstimes.com/economy/european-countries-by-gdp-per-capita.php

Todd, J. (2007). The Impact of Foreign Aid on Development and Aggregate Welfare of Developing Countries. Illinois: Illinois Wesleyan University.

Trading Economics. (2019, November 20). Nigeria GDP Per Capita. Retrieved from Trading Economics: https://tradingeconomics.com/nigeria/gdp-per-capita

United Nations. (2017, 12 22). United Nations Sustainable Development Agenda. Retrieved from United Nations: http://www.un.org/sustainabledevelopment/development-agenda/

United Nations Development Programme. (2017, November 20). Sustainable Development Goals. Retrieved from UNDP: http://www.undp.org/content/undp/en/home/sustainable-developmentgoals.html

World Bank. (2017, November 20). Sustainable Development. Retrieved from World Bank: http://www.worldbank.org/en/topic/sustainabledevelopment 